\title{
The implications of social responsibility in reducing youth unemployment in Romania
}

\author{
Sorina-Geanina STANESCU, Ana-Maria COMANDARU \\ Valahia University of Targoviste, Romania
}

\begin{abstract}
:
Aim: Lately, there is more and more discussion about sustainable development and social responsibility within organizations, thus increasing the pressure on organizations and managers to act ethically and responsibly. The main purpose of this study is to present how Romanian businesses have integrated aspects of social responsibility into the decision-making and management systems of organizations. The study focuses on identifying the main factors behind the development of the concept of social responsibility and presenting the link between economic activity and sustainable development. A major focus of this research is the study on the implications of corporate social responsibility in reducing the number of youth unemployment at national level.
\end{abstract}

Design/Research methods: As far as the methodology of research is concerned, we will start from the theoretical documentation and we will continue with empirical research, using descriptive analysis and statistical interpretation of data as the main research methods.

Conclusions/findings: Empirical research conducted in this paper allowed us to observe the involvement of organizations in adopting support measures for the social problems of young people unemployed.

Originality/value of the article: Social responsibility is a vast concept that is growing in Romania and the implication of this concept in solving unemployment has led us to realize the present research that we want to add value to both the business environment in Romania and young researchers interested in this field.

Keywords: management, social responasability, youth unemployment. JEL: Q56

Correspondence address: Sorina-Geanina STANESCU, Ana-Maria COMANDARU, Valahia University of Targoviste, Romania. E-mail: geaninastanescu@ yahoo.com

Received: 18.07.2018, Revised: 07.09.2018, Revised: 12.10.2018, Revised: 11.12.2018, Accepted: 11.12.2018

doi: http://dx.doi.org/10.29015/cerem.749 


\section{Introduction}

The Corporate Social Responsibility (CSR) has become an important topic in organizational management - both for practitioners and for theoreticians. The results of production systems can have negative effects on the environment, thus taking into account these elements is the basis for sustainable development within companies (Margarit, Bran 2011).

Corporate Social Responsibility means respecting ethical and moral obligations in the economic, social and environmental spheres. Companies are trying to communicate as clearly as possible the key elements of their ethical practices, so more and more companies, including Romania's companies, have published sustainability reports lately (Stanescu 2017). This is only a confirmation of what the benefits of social responsibility involve in the corporate management system.

\section{Global and European Corporate Social Responsibility}

Corporate Social Responsibility, a concept that emerged after the Second World War, quickly became a desideratum for companies wishing to advance economically and socially. Gradually, more and more fierce competitiveness in the business environment has transformed the concept of corporate social responsibility from the target into demand for most businesses.

Specialized literature abounds in concept definitions, however there is no standardized definition of what corporate social responsibility means. One of the best-known definitions is given by the World Business Council for Consumable Development in 1998; they define corporate social responsibility as "continuing commitment by business to contribute to economic development while improving the quality of life of the workforce and their families as well as of the community and society at large".

Another definition of corporate social responsibility is given by researcher Archie Carroll who identified four elements of the concept; initially in 1979, Carroll enumerated and emphasized the importance of the following responsibilities of a 
company integrating a strategic CSR program: economic, legal, ethical and discretionary responsibility. A few years later, in 1991, the same author offered a new version of the previously defined definition by replacing the idea of discretion with philanthropy, creating Pyramid of Corporate Social Responsibility (see Figure $1)$.

\section{Figure 1. Pyramid of Corporate Social Responsibility}

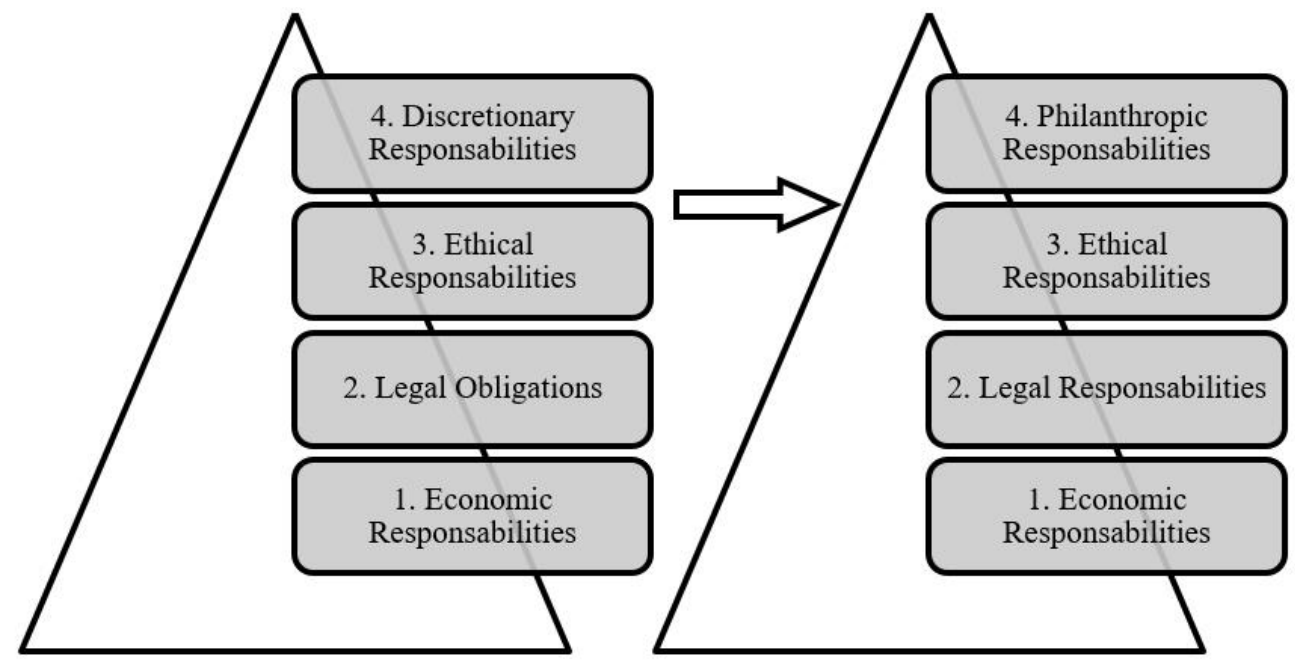

Carroll, 1979.

Carroll, 1991.

Source: Adaptation of Carroll (1991).

The CSR pyramid remained very important in the literature and was commented by numerous researchers. The four levels of the corporate social responsibility pyramid were reinterpreted and explained as follows:

1. Economic - the responsibility to earn after stakeholder investment;

2. Legal - the responsibility to comply with the law;

3. Ethics - the responsibility to adhere to social norms uncodified by laws but expected by the actors operating in society;

4. Philanthropic - the responsibility to have a defined role in voluntary help for a segment of the society (Burton, Goldsby 2009). 
At the level of the European Union, corporate social responsibility is an area of interest for the authorities, so the European Commission recognizes its importance in the context of sustainable development and gives us another definition: "a concept whereby companies integrate social and environmental concerns in their business operations and in their interaction with their stakeholders on a voluntary basis" (Commission of the European Communities 2001).

Thus, in the opinion of the European authorities, a corporate social responsibility program has two characteristics: firstly it is based on the moral responsibility of companies that create a long-term profitable relationship system; secondly, it emphasizes its voluntary nature, because it does not there is a legal basis that requires companies to apply the CSR program. The Commission promotes CSR in the European Union and encourages enterprises to adhere to international guidelines and principles. To evaluate the CSR strategy, the Commission launched a Public Consultation on CSR 2011-2014: achievements, shortcomings, and future challenges in 2014. The European Union's policy is built on an agenda for action to support this approach. It includes

\section{Figure 2. The CSR strategy of European Union}

- Enhancing the visibility of CSR and disseminating good practices

Source: http://ec.europa.eu/growth/industry/corporate-social-responsibility_en [07.05.2019]. 
Although Corporate Social Responsibility programs involve significant costs from companies, they are profitable management strategies while providing trust and credibility to the actions taken by the entity. Moving from the main business goal to achieving business success implies a deeper strategic approach from management, a strategy that is based on three categories of objectives: economic (making profits, reinvesting it and creating value added), social (equitable participation of all social groups) and ecological (rational use of limited resources).

The European approach to CSR enables the concept of sustainable development for businesses to be operational. In practical terms, the social responsibility is associated with the "triple-bottom-line" concept: economic prosperity, respect for the environment, respect for and improvement of social cohesion (see Figure 3). (Hristea 2011).

Corporate Social Responsibility contributes to the sustainable development of companies that choose to integrate the environmental and social issues faced by modern human society. In other words, everyone benefits from the use of social responsibility programs: the company that paves its way to business success by increasing profits and creating long-lasting relationships with the stakeholder and disadvantaged communities that receive support for local development.

Figure 3. The Impact of Corporate Social Responsibility on human society

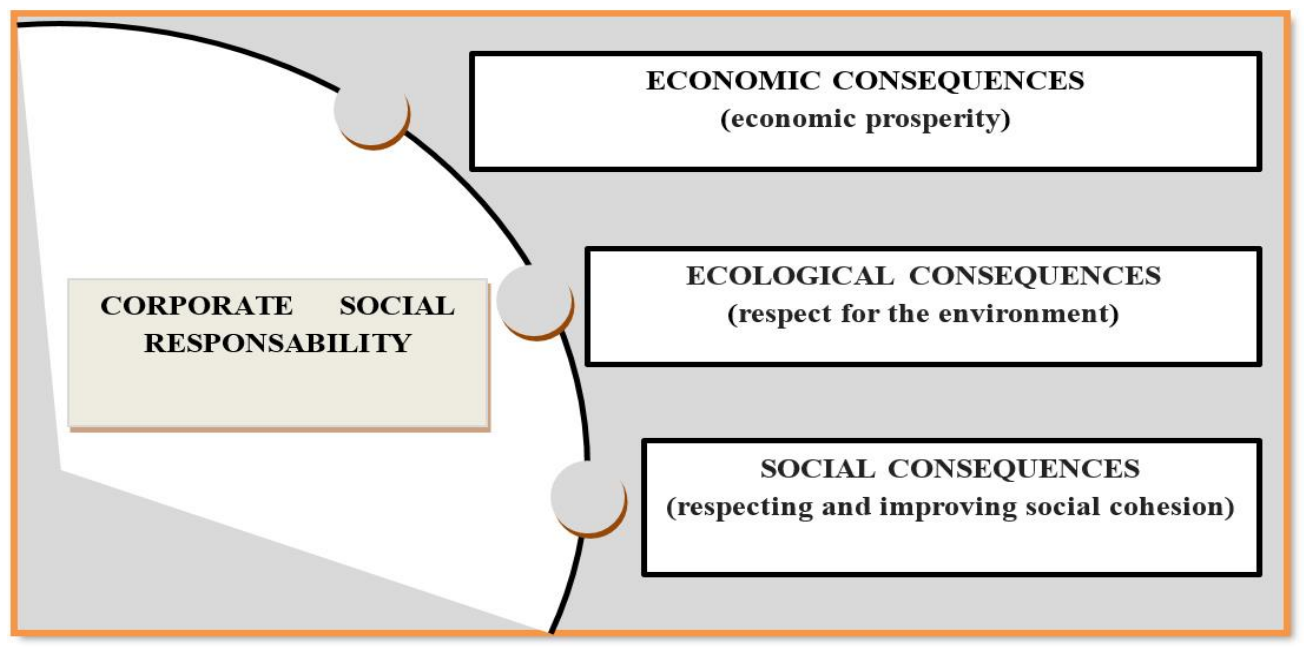

Source: Adaptation of Hristea (2011). 


\section{The main directions of Corporate Social Responsibility}

Corporate Social Responsibility programs have an impact on the environment in which the enterprise operates, influencing:

- Internal environment - company management, shareholders, employees.

- External environment - suppliers, customers, competitors, state, banks, trade unions, civil society, etc.

In the first case, the factors that focus on the internal environment of the company are treatment of women and minorities, employee relations and advancement potential. In the second case the factors that focus on the external environment are treatment of the environment, external perceptions of quality and external perceptions of employee compensation due to marketplace comparisons. (Rothbardt 2012).

At international level, companies that choose to integrate the concept of CSR into their businesses have four lines of action: respecting the human rights, respecting labor standards, protecting the environment, and fighting corruption. By implementing CSR programs, businesses promote moral values and principles, business ethics is a benchmark for managers who aim not only at meeting economic goals but also engaging in sustainable development of society.

By adopting effective CSR programs, companies can benefit from multiple facilities: cost savings, brand image enhancement, incentives and motivation for employees, optimizing opportunities for access to capital, attracting customers and increasing turnover, reducing risks (Hristea 2011).

Studying the literature, we can conclude that the main directions of action of the social responsibility programs of the companies materialize in:

a) Promoting business ethics standards;

b) Defending the rights of employees and create safe working conditions for them;

c) Developing programs to prevent employee discrimination;

d) Developing training programs for the unemployed;

e) Supporting equal opportunities by protecting the rights of women, children, the elderly, minorities;

f) Promoting and sustaining culture, art; 
g) Supporting educational institutions;

h) Promoting and developing consumer protection programs;

i) Protecting the environment, etc.

\section{Corporate social responsibility in Romania}

The concept of corporate social responsibility originated in the United States of America and began to be promoted at European level in the mid-1980s. In Romania, CSR emerged after 1990 when multinational companies entered the economic environment and implemented principles and practices in this sphere.

Gradually, the social responsibility actions of foreign companies in Romania have intensified and have become a constant concern for them in the context of the implementation of sustainable development strategies. The practices of multinational companies in the field of CSR have been an example for Romanian companies that have allocated significant budgets for running programs that have preoccupations with economic, social and environmental concerns.

After 2000, corporate social responsibility has become a growing phenomenon in Romania's business environment, and Romanian companies have responded to a new challenge: the issue of reporting and transparency of CSR activities. The drafting of sustainability reports is a current concern for businesses, given the importance of communicating and consolidating the public image of companies. Unfortunately, studies conducted in the field of corporate social responsibility in Romania show that "the availability of companies to communicate information on CSR activity is limited" (www.amfiteatrueconomic.ro).

Another concern of Romanian companies is, or should be, identifying the needs of the communities in which they operate. Research in the field contradicts the fact that Romanian companies base their social responsibility activities on the basis of scientific diagnoses, of course, with exceptions for large companies. The reasons why the needs of the community are not correctly identified are multiple: lack of local development strategies, lack of corporate CSR compartments, decision-making 
without stakeholder consultation, confusion of CSR with sponsorship, limiting the budgets that companies put the provision of CSR activities, etc.

Most companies in Romania carry out CSR activities in areas such as education (including professional development of their own employees), social, environment, followed by culture and art, and other areas with less attention (Obrad et al. 2011).

Given that there is a social and economic framework in development in Romania, the concept of corporate social responsibility should go beyond the idea of strengthening the image of the firm and be viewed more and more as what is at European and world level: an essential element of long-term success that is closely linked to the social and environmental performance of the community.

\section{Study on the implications of corporate social responsibility in reducing youth unemployment in Romania}

Social responsibility has a very important role in the European Union, in the lives of Europeans and their families, and in terms of their influence in promoting society and the economy. Ethics and social responsibility intertwine. Corporate Social Responsibility is the concern of managers to protect and improve the welfare of society, its organization and its members. Social responsibility includes the adoption of a position of support for public issues and disadvantaged groups. For example, the company's social responsibility divisions can include: job creation for young unemployed, development of youth inclusion programs, training and improvement programs for young unemployed.

Youth unemployment is a problem that the European Union has been experiencing for some time. The decrease in the number of unemployed in general and the number of unemployed young people, in particular, is a continuing concern for the European community and is a challenge for the Romanian authorities. In support of authorities, companies have developed social responsibility programs whose ultimate goal is the professional development of young people and training to meet the demands of the labor market. Through the development of vocational and technical education, through the achievement of student internships in the big 
companies, the acquisition of professional competencies at the workplace and the adaptation of the human resources to the organizational environment of the enterprise is desired (Sustainability Report, Electrica S.A. 2016). More and more Romanian companies have allocated significant sums for the implementation of CSR programs in the field of education, programs, together with personal development courses, professional orientation and practical workshops specific to the profession that the student is studying. Providing financial support (scholarships) to students in technology high schools, especially those in vocational education, job security after graduation, practical training for the labor market are just some of the advantages the big companies offer in their attempt to reduce the youth unemployment phenomenon.

The research is aimed at appreciating the efforts of the Romanian authorities with those of the companies that carry out CSR activities in order to reduce the youth unemployment. The data necessary for the analysis of the unemployment phenomenon affecting the population from the age group 15-24 years were taken from the statistical yearbook of Romania for the period 2013-2016, data published on the site www.insse.ro, Table 1.

The evolution in the period 2013-2016 of the unemployment rate and the youth unemployment rate (age group 15-24) is shown in Figure 4. The unemployment rate in Romania has decreased continuously, decreasing by almost one percentage point 2013 by the end of 2016 (favorable situation). On the other hand, the youth unemployment rate fluctuated, so there is a slight increase in 2014 compared to 2013 (by $0.4 \%$ ) and in 2015 and 2016 this will decrease.

It is worth noting that in 2016 as compared to 2013 the decrease of the unemployment rate for the age group of 15-24 years is 3 percentage points, in this context we interpret the evolution of the indicator as a seemingly favorable one, because the efforts made to reduce the unemployment among the youth effect, but the results still place Romania above the EU average (e.g. in 2016 the unemployment rate for the 15-24 age group was $20.4 \%$ compared to the EU average of $17.4 \%)$. 
Table 1. Statistical indicators of unemployment in Romania in 2013-2016 (age group 15-24 years)

\begin{tabular}{|c|c|c|c|c|}
\hline Indicators & $\begin{array}{l}\text { Year } \\
2013\end{array}$ & $\begin{array}{l}\text { Year } \\
2014\end{array}$ & $\begin{array}{l}\text { Year } \\
2015\end{array}$ & $\begin{array}{l}\text { Year } \\
2016\end{array}$ \\
\hline Unemployment rate & $7.10 \%$ & $6.80 \%$ & $6.80 \%$ & $5.90 \%$ \\
\hline Registered unemployment rate & $5.70 \%$ & $5.40 \%$ & $5 \%$ & $4.80 \%$ \\
\hline Youth unemployment rate ( $<25$ years) & $23.60 \%$ & $24 \%$ & $21.70 \%$ & $20.60 \%$ \\
\hline $\begin{array}{l}\text { Unemployment rate }(15-24 \text { years })- \\
\text { male }\end{array}$ & $23.50 \%$ & $23.60 \%$ & $23.40 \%$ & $19.90 \%$ \\
\hline $\begin{array}{l}\text { Unemployment rate (15-24 years) - } \\
\text { female }\end{array}$ & $23.90 \%$ & $24.70 \%$ & $20.60 \%$ & $21.80 \%$ \\
\hline $\begin{array}{l}\text { Unemployment rate ( } 15-24 \text { years })- \\
\text { urban }\end{array}$ & $33.30 \%$ & $32.60 \%$ & $26.90 \%$ & $24.90 \%$ \\
\hline Unemployment rate (15-24 years) - rural & $17.10 \%$ & $18.30 \%$ & $18.50 \%$ & $18.30 \%$ \\
\hline Employment rate (15 -24 years) & $22.90 \%$ & $22.50 \%$ & $24.50 \%$ & $22.30 \%$ \\
\hline $\begin{array}{l}\text { Long term unemployment rate for young } \\
\text { people * (aged } 15-24 \text { years) }\end{array}$ & $14.20 \%$ & $14.30 \%$ & $13.10 \%$ & $13 \%$ \\
\hline $\begin{array}{l}\text { Incidence of long term unemployment } \\
\text { for young } \\
\text { people* (aged } 15-24 \text { years) }\end{array}$ & $59.90 \%$ & $59.70 \%$ & $60.60 \%$ & $63.10 \%$ \\
\hline \multicolumn{5}{|c|}{ Note: * Unemployed for 6 months and over } \\
\hline
\end{tabular}

Source: Data downloaded by authors, available at www.insse.ro.

Analyzing the unemployment rate by age group, we notice that in each of the 4 years, the indicator was highest among young people (15-24 years), Figure 4. 
Figure 4. Evolution of the youth unemployment rate as compared to the unemployment rate registered in Romania during the period 2013-2016

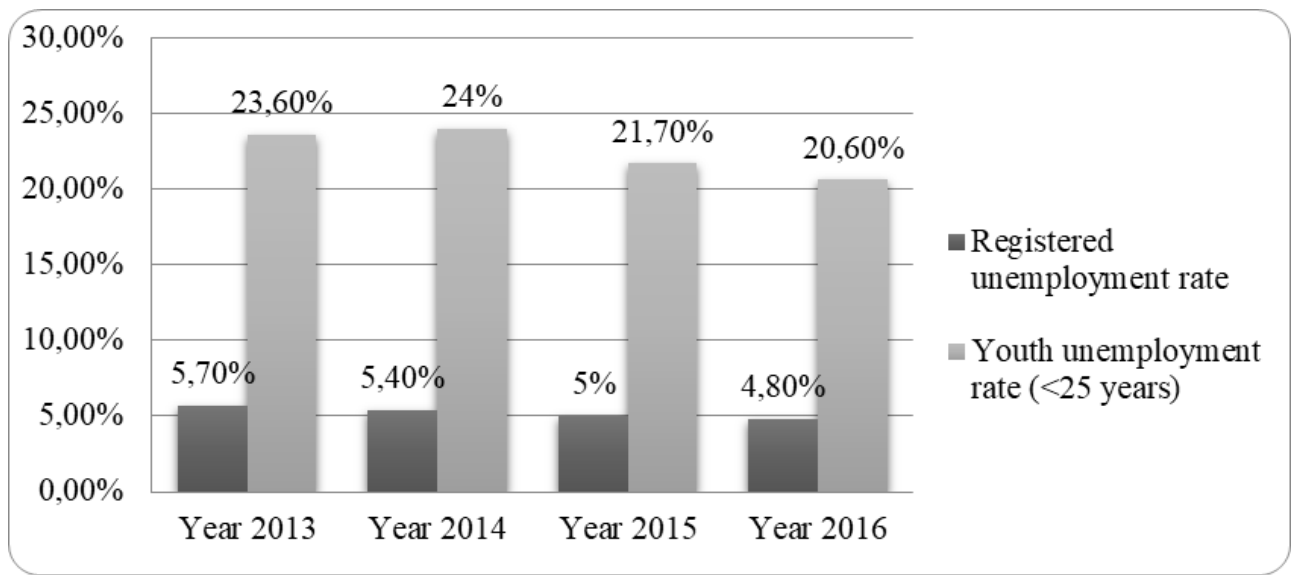

Source: Data processed by authors, available at www.insse.ro

The evolution of the unemployment rate for the 15-24 age group by gender and by average over the period 2013-2016 is shown in Figures 5 and Figure 6 .

Analyzing Figure 5, we can see that there are no major differences between men and women aged 15-24 in terms of unemployment: In the years 2013-2014, the female unemployment rate was higher than that among men, but the gap was small, of $0.4 \%$ in 2013 and $1.1 \%$ in 2014 respectively. The situation is reversed over the next two years when the female unemployment rate was lower than that among men, with nearly 3 percent being registered in 2015 (See Figure 5). 
Figure 5. Youth unemployment rate by gender, 2013-2016

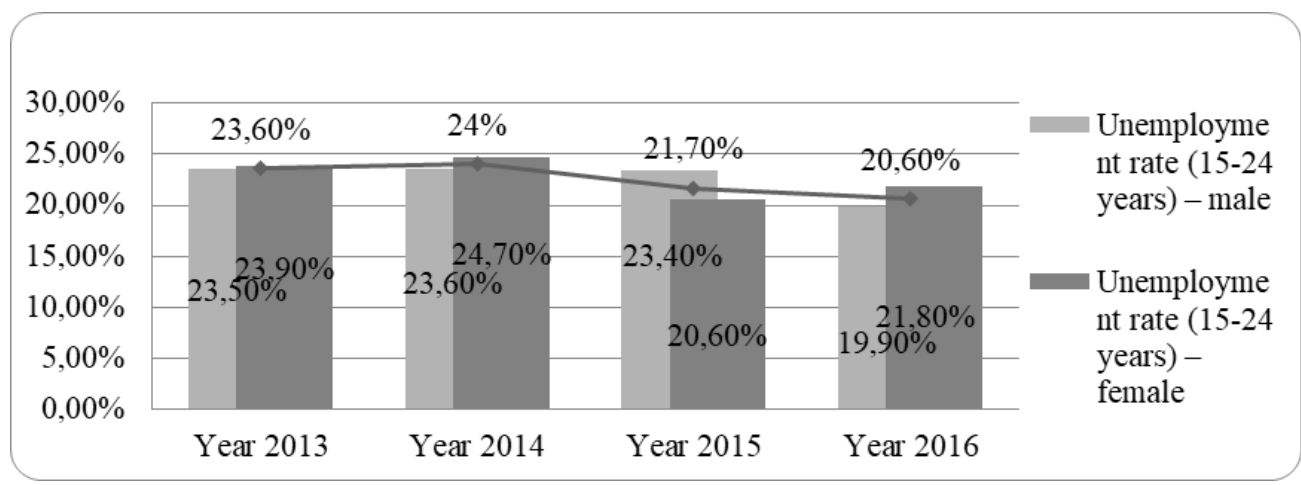

Source: Data processed by authors, available at www.insse.ro

Concerning the environment of the unemployed youth, Figure 6 highlights the fact that, during the analyzed period, people in the urban area are more affected by unemployment than those in rural areas. We note the tendency to decrease the unemployment rate of young people in the urban environment and we believe that this has happened to a small extent due to the slight increase of the unemployment rate among young people in rural areas and to a higher extent due to the decrease of the unemployment rate for the category of aged 15-24 (See Figure 6).

Figure 6. Unemployment rate among young people, by area, in 2013-2016

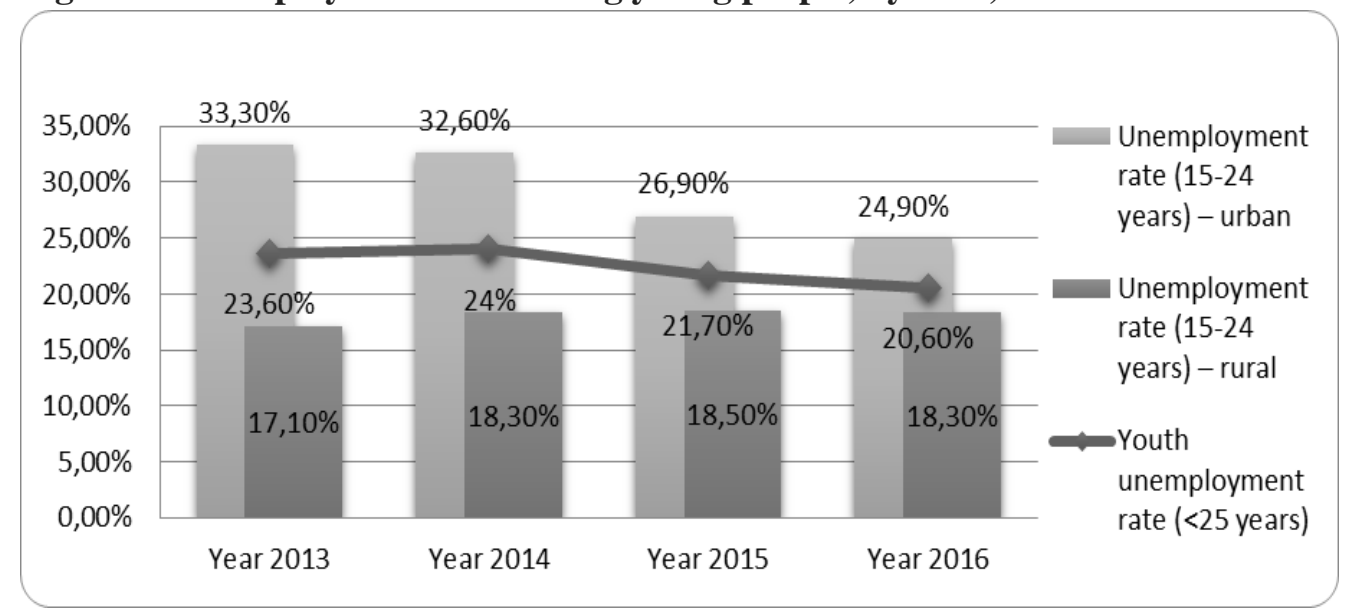

Source: Data processed by authors, available at www.insse.ro 
In the analysis of unemployment indicators, the occupancy rate of the population is also an important factor. The employment rate of the young people represents the share of the employed population in the 15-24 age group in the total population of the same age group.

A high occupancy rate for the population aged 15-24 would reduce the youth unemployment rate. This is also evident from Figure 7, so that in the years 20132014 the youth employment rate is lower than the unemployment rate for this age group and in the years 2015-2016 the youth unemployment rate is lower than the employment rate (inversely proportional relationship), Figure 7.

\section{Figure 7. Evolution of the occupancy rate compared to the evolution of the} unemployment rate, age group 15-24 years

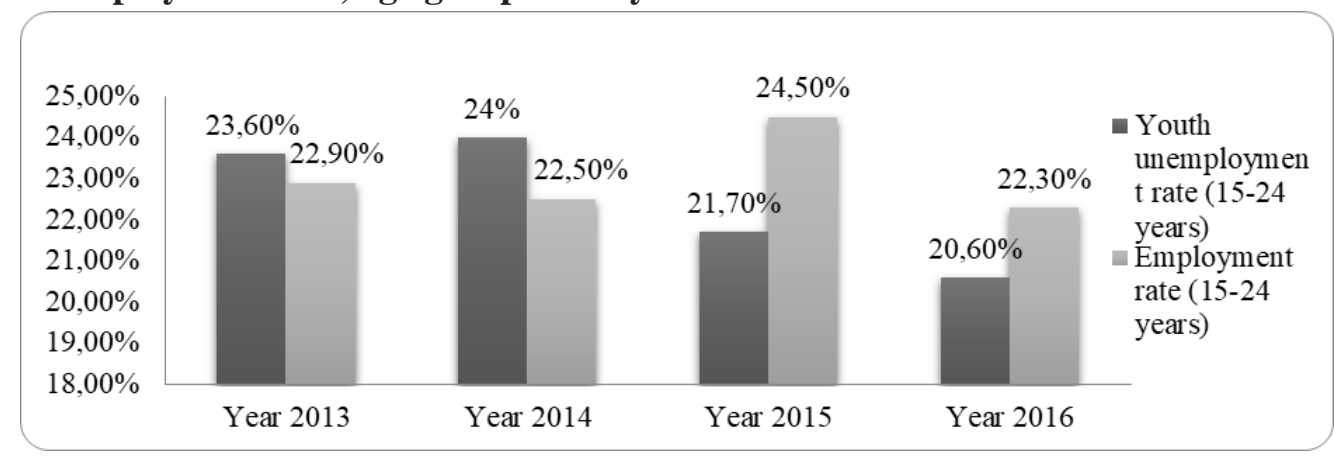

Source: Data processed by authors, available at www.insse.ro

As a conclusion of this research, we can say that the population aged 15-24 is the most vulnerable on the Romanian labor market: during the analyzed period, the youth unemployment rate reached the highest level, compared to the others age categories in national statistics, so we believe that the involvement of national companies through the implementation of social responsibility programs that aim at integrating young unemployed into the workplace can be an important factor in reducing unemployment in Romania. 


\section{Conclusions}

Corporate Social Responsibility is a commitment that companies undertake to contribute to the economic development of the community in which they operate.

The process of globalization, the development of information technologies, the protection of the environment and the consolidation of human rights are just a few of the factors that have led to the development of this concept that brings the business community closer together.

In Romania, the concept of corporate social responsibility was imported with the entry of multinational companies into the domestic market. Gradually, more and more Romanian companies understood the importance of CSR and allocated significant budgets for the implementation of social and environmental programs.

Awareness of the fact that making profits no longer ensures business success, that the company's sustainable development represents the "future" of the company we live in, has led businesses to adopt consistent strategies in the field of corporate social responsibility based on solid values: ethics, transparency, credibility, integrity.

Caring for the environment, employees and the community make corporate social responsibility an important phenomenon of the contemporary world and a reality of the business environment.

As presented in this research, social responsibility includes the adoption of a position of support for public issues especially among young unemployed. On the basis of the statistical interpretations we could conclude that it is very important for economic organizations to include among their social responsibility departments programs that will provide jobs for young unemployed and develop programs aimed at employing young unemployed. Dropping unemployment is a continuing concern for authorities and it is also for companies who understand the importance of this phenomenon and the need to find solutions that are as effective and quick as possible to solve it. 


\section{THE IMPLICATIONS OF SOCIAL RESPONSIBILITY IN REDUCING ...}

\section{References}

Berger-Douce S. (2008), Rentabilité et pratiques de RSE en milieu PME premiers résultats d'une étude française, „Management \& Avenir”, vol. 1 no. 15, pp. 9-29.

Blowfield M. (2005), Corporate Social Responsibility. Reinventing the meaning of development?, „International Affairs”, vol. 81 no. 3, pp. 515-524.

Burton B., Goldsby M. (2009), Corporate Social Responsibility orientation, goals and behavior. A study of small business owners, „Business and Society”, vol. 48 no. 1, pp. 88-104.

Caroll A.B. (1991), The pyramid of corporate social responsibility. Towards the moral management of organizational stakeholders, „Business Horizons”, no. 34, pp. 39-48.

Commission of the European Communities (2001), Green Paper. Promoting a European framework for Corporate Social Responsibility, http://ec.europa.eu/transparency/regdoc/rep/1/2001/EN/1-2001-366EN-1-0.Pdf [31.05.2019].

Garriga E., Melé D. (2004), Corporate Social Responsibility theories. Mapping the territory, „Journal of Business Ethics", vol. 53 no. 1-2, pp. 51-71.

Gordon J.A., Rogene A.B. (1978), Corporate Social Responsibility and stock market performance, „Academy of Management Journal”, vol. 21 no. 3, pp. 479-486.

Hristea A.M. (2011), Responsabilitatea sociala corporativa - intre deziderat si realitate, „Economie Teoretica si Aplicata", vol. XVIII no. 10, pp. 56-73, http://store.ectap.ro/articole/650_ro.pdf [07.05.2019].

Margarit (Stanescu) S.G., Bran (Stan) N.C. (2011), Relevance of economic instruments used in sustainable development process, „Annals of the University of Petroşani, Economics”, vol. 11 no. 3, pp. 155-166.

Obrad C., Petcu D., Gherghes V., Suciu S. (2011), Responsabilitatea sociala a companiilor din România intre perceptii si realitate, „Amfiteatrul Economic”, vol. III no. 29, http://www.amfiteatrueconomic.ro/temp/Articol_1014.pdf [07.05.2019].

Rothbardt J.L. (2012), Applicant attraction to socially responsible organizations. The moderating effect of core self-evaluation, doctoral thesis, St. Ambrose University, pp. 1-70.

Stanescu S.G. (2017), Dezvoltarea si implementarea contabilitatii mediului, Valahia University Press, Târgovişte,

World Business Council of Sustainable Development (1998), WBCSD - Corporate Social Responsibility.0020, http://www.wbcsd.org/DocRoot/hbdf19Txhmk3kDxBQDWW/CSRmeeting.pdf [07.05.2019].

WBCSD (2016), Corporate Social Responsibility, https://growthorientedsustainableentrepreneurship.files.wordpress.com/2016/07/csr-wbcsd-csrprimer.pdf [31.05.2019]. 
Sorina-Geanina STANESCU, Ana-Maria COMANDARU

\section{Websites}

www.responsabilitate-sociala.org

www.insse.ro 